\title{
Pengaruh Budaya Organisasi Terhadap Kinerja Karyawan Melalui Motivasi Sebagai Variabel Intervening Studi pada PT. Rahmat Jaya Perkasa Sidoarjo
}

\author{
Najmy Haqq \\ Universitas Negeri Surabaya \\ najmyhaqq@gmail.com
}

\begin{abstract}
PT. Rahmat Jaya Perkasa is a company focuses on ceramic tile's distribution in East Java region. To improve and maintain the quality of its services, the company focuses on their organization culture. This process is done so that the organization within the company can improve employee performance to maintain its competitive advantage. In order to improve the performance of employees is needed motivation to work so that the organization can maintain its competitive advantage. Thus, the purpose of this study was to analyze the influence of organizational culture, employee performance and motivation. And the role of mediation motivation to work on the influence of organizational culture on employee performance. Samples from this study are all permanent employees of PT. Rahmat Jaya Perkasa, which are 42 employees. Data analysis technique used is the analysis with alternative methods of Structural Equation Model Partial Least Square with the help of software Smart PLS 3.0. The results of the study explained that organizational culture significantly influence employee performance. Organizational culture positive and significant effect on work motivation. Work motivation significantly influence employee performance. Work motivation is not mediating effect of organizational culture on employee performance.
\end{abstract}

Keywords : organizational culture, employee performance, motivation

\section{PENDAHULUAN}

Perkembangan pembangunan di indonesia meningkat pesat hal ini ditandai dengan meningkatnya Infrastruktur di Indonesia. Berdasarkan Badan Koordinasi Penanaman Modal (BKPM) nilai investasi hingga triwulan III 2015 dibidang infrastruktur mencapai Rp. 90,5 triliun. Angka tersebut terus tumbuh 12,4 persen dibandingkan periode yang sama tahun 2014 (www.presidenri.go.id). Salah satu bidang infrastruktur tersebut adalah industri keramik.

Industri keramik menjadi salah satu produk unggulan dalam negeri. Hal itu di tunjukkan dengan total penjualan industri keramik dalam negeri pada tahun 2014 mencapai Rp. 30 triliun dan diprediksi meningkat tahun 2015 mencapai Rp. 36 triliun (www.antaranews.com). Industri keramik di Indonesia juga merupakan Perubahan persaingan dalam industri keramik yang semakin kompetitif membuat perusahaan harus berjuang memperbaiki kondisi internal maupun eksternal perusahaan. Keadaan tersebut juga berdampak pada persaingan industri keramik yang semakin kompleks dan kompetitif.

Persaingan industri keramik yang kompetitif dapat ditunjang dengan sumber daya manusia yang kuat. Menurut Kesuma (2007) perusahaan yang memiliki keinginan menghasilkan karyawan yang profesional dengan integritas yang tinggi, diperlukan adanya acuan baku yang diberlakukan oleh suatu perusahaan. Acuan baku tersebut adalah budaya organisasi yang secara sistematis menuntun karyawan untuk meningkatkan kinerjanya bagi perusahaan.

Menurut Wibowo (2012:471) Budaya adalah apa yang dilakukan orang dan apa arti tindakan mereka bagi mereka. Budaya organisasi dapat didefinisikan sebagai perangkat sistem nilai-nilai (values), keyakinan-keyakinan (beliefs), asumsi-asumsi atau norma yang telah berlaku, disepaakati dan diikuti oleh para anggota suatu organisasi sebagai pedoman perilaku dan pemecahan masalah-masalah organisasinya. Dalam budaya organisasi terjadi sosialisasi nilai-nilai dan menginternalisasi dalam diri para anggota, menjiwai orang per orang didalam organisasi. Dengan demikian, maka budaya organisasi merupakan jiwa organisasi dan jiwa para anggota organisasi. Budaya yang kuat dan positif sangat berpengaruh kuat terhadap organisasi salah satunya adalah pengarahan perilaku dan kinerja organisasi. (Kilmann dkk., (1988) dalam Sutrisno, 2011:2)

Kinerja (prestasi kerja) adalah hasil kerja secara kualitas dan kuantitas yang dicapai oleh seorang karyawan dalam melaksanakan tugasnya sesuai dengan tanggung jawab yang diberikan kepadanya (Mangkunegara, 2015:67). Untuk mengukur keberhasilan pencapaian kinerja karyawan dilakukan penilaian. Menurut Mangkunegara (2015:69) penilaian prestasi pegawai adalah suatu proses penilaian prestasi kinerja pegawai yang dilakukan pemimpin perusahaan secara sistematik berdasarkan pekerjaan yang ditugaskan kepadanya. Perusahaan PT. Rahmat Jaya Perkasa melakukan penilaian kinerja sebulan sekali secara berkala pada akhir bulan dan dilakukan oleh atasan langsung. Atasan langsung yang dimaksudkan adalah orang yang bertanggung jawab secara langsung pada kinerja karyawan dibawahnya. Seperti kepala gudang membawahi delapan orang bawahannya. Penilaian ini bertujuan untuk mengetahui perkembangan kinerja karyawan. PT. Rahmat Jaya Perkasa melakukan penilaian kinerja berdasarkan empat dasar penilaian antar lain kualitas, kuantitas, dapat diandalkan dan sikap.

Studi yang dikemukakan oleh Indraswari dan Djastuti (2014) membuktikan bahwa budaya organisasi memiliki pengaruh yang positif terhadap kinerja karyawan. Hal ini sejalan dengan penelitian dari Sinha et al (2010), dan Krisdiyanto (2010) yang menyatakan pengaruh budaya organisasi berpengaruh positif terhadap kinerja karyawan. Namun, sebaliknya penelitian dari Lina (2012), Kesuma (2007) dan Susanto dan Aisiyah (2010) membuktikan bahwa budaya organisasi tidak memiliki pengaruh terhadap kinerja karyawan. 
Menurut Sinha et al (2010) budaya dalam sebuah perusahaan akan mempengruhi cara berfikir karyawan sehingga mempengaruhi kinerja perusahaan. Budaya organisasi berdampak pada kinerja dalam jangka panjang, bahkan mungkin faktor terpenting dalam menentukan keberhasilan dan kegagalan organisasi (Tan, 2002:21 dalam Wibowo, 2012:487).

\section{Tabel 1.1}

Budaya Organisasi PT. Rahmat Jaya Perkasa

\begin{tabular}{|l|l|}
\hline Budaya Organisasi & Penjelasan \\
\hline Profesional & $\begin{array}{l}\text { Keterampilan dan kecakapan yang dibutuhkan dalam kaitannya dengan profesi } \\
\text { serta fungsi, tugas, dan kewajiban jabatan. }\end{array}$ \\
\hline Penerapan di perusahaan & $\begin{array}{l}\text { Pelaksanaan budaya ini seperti divisi operasional yang bertanggung jawab } \\
\text { terhadap pengiriman dan pengadaan barang. Perusahaan memiliki konsep tepat, } \\
\text { cepat, dan terpercaya. }\end{array}$ \\
\hline Integritas & $\begin{array}{l}\text { Dapat dipercaya, jujur, konsisten dalam memahami dan keinginan untuk } \\
\text { menyesuakan diri dengan nilai-nilai dan kebijakan organisasi serta mematuhi } \\
\text { etika profesi dan bisnis. }\end{array}$ \\
\hline Penerapan di perusahaan & $\begin{array}{l}\text { Pelaksanaan budaya integritas dalam perusahaan ditunjukkan dengan mematuhi } \\
\text { aturan yang ada dalam perusahaan dan dapat dipercaya dalam melaksanakan tugas } \\
\text { seperti dalam bagian keuangan, kejujuran dibutuhkan dalam perhitungan } \\
\text { keuntungan serta menghitung jumlah tagihan tiap toko. }\end{array}$ \\
\hline Inovasi & $\begin{array}{l}\text { Kemampuan untuk mengembangkan ide, gagasan, pendekatan baru dan inovatif } \\
\text { yang aplikatif untuk dapat melakukan pekerjaan lebih efektif dan efisien dalam } \\
\text { rangka melakukan perubahan untuk perbaikan dan berani mengambil resiko. }\end{array}$ \\
\hline Penerapan di perusahaan & $\begin{array}{l}\text { Dalam perusahaan budaya inovasi dilakukan dengan adanya pencatatan stock } \\
\text { barang dilakukan ganda dimana pencatatan dilakukan secara manual dan } \\
\text { menggunakan komputer. Hal ini dilakukan untuk meminimalisir kesalahan yang } \\
\text { dibuat oleh manusia ataupun perhitungan computer }\end{array}$ \\
\hline Teamwork & $\begin{array}{l}\text { Suatu bentuk kerja sama dalam melakukan suatu pekerjaaan yang dilakukan oleh } \\
\text { beberapa orang dalam mencapai penyelesaian tugas terbaik }\end{array}$ \\
\hline Penerapan di perusahaan & $\begin{array}{l}\text { Pelaksanaan budaya teamwork dalam perusahaan seperti adanya rapat tiap hari } \\
\text { senin untuk membahas masalah dan mencari penyelesaian bersama selain itu kerja } \\
\text { sama pada satu divisi akan membuat tugas atau persoalan dapat terselesaikan } \\
\text { dengan jalan musyawarah. }\end{array}$ \\
\hline Orientasi pelayanan. & $\begin{array}{l}\text { Budaya orientasi pelanggan ini dilakukan dengan cara melayani pelanggan } \\
\text { dengan menjawab seluruh pertanyaan mengenai produk dan melayani komplaim } \\
\text { pelanggan selama jam kerja selain itu pelayanan komlain maksimal 3 x 24 jam. }\end{array}$ \\
\hline Penerapan di perusahaan
\end{tabular}

Sumber : Data wawancara 14 April , 2016
Dalam perusahaan PT. Rahmat Jaya Perkasa, Budaya perusahaan terdiri dari Profesional, Integritas, Inovasi , Teamwork dan Orientasi pelanggan. Kelima nilai budaya ini menjadi aspek penting PT. Rahmat Jaya Perkasa sebagai perusahaan distributor keramik di Jawa Timur.
Pelaksanaan budaya organisasi profesionalitas, dalam kenyataannya pengiriman yang tepat, cepat dan terpercaya terkadang memiliki banyak kendala seperti kesalahan dalam pengiriman kualitas keramik yang dipesan oleh toko. Pelaksanaan budaya integritas, dalam kenyataannya dalam perusahaan terlaksana dengan baik hal ini dibuktikan dengan lebih banyak karyawan yang menaati aturan perusahaan. Pelaksanaan budaya inovasi dalam kenyataannya budaya inovasi dalam melakukan pencatatan ganda dilakukan dengan baik namun terkadang masih ada pencatatan yang berbeda atau tidak sesuai. Dalam pelaksanaan budaya teamwork dalam perusahaan, kenyataannya berjalan dengan baik. Karyawan aktif mengikuti rapat yang diadakan tiap hari senin. Dalam pelaksanaan budaya orientasi pelanggan kenyataannya komplain yang dimasukkan terkadang sampai $4 \times 24$ jam dikarenakan adanya pengecekan ulang dibagian yang bersangkutan.

Menurut personalia PT. Rahmat Jaya Perkasa pelaksanaan budaya dalam perusahaan telah berjalan dengan baik, hal ini ditandai dengan penghargaan Best Performance pada tahun 2006 dan 2007. Penghargaan ini diberikan oleh PT. Diamond Ceramics Industries sebagai penghargaan pada distributor dengan omset tertinggi dan pembayaraan tepaat waktu. Selain itu, keberhasilan budaya organisasi dapat dibuktikan dengan berkurangnya komplain pelanggan tiap tahunnya. Budaya organisasi yang diharapkan dapat meningkatkan kinerja karyawan nampaknya tidak berjalan dengan baik. Hal ini di tunjukkan dengan menurunnya kinerja karyawan PT. Rahmat Jaya Perkasa yang ditunjukkan pada tabel dibawah

Tabel 1.2

\begin{tabular}{|c|c|}
\hline Bulan & $\begin{array}{c}\text { Hasil rata-rata penilaian kinerja } \\
\text { karyawan }\end{array}$ \\
\hline
\end{tabular}




\begin{tabular}{|c|c|}
\hline Juli & 3,5 \\
\hline Agustus & 3,59 \\
\hline September & 3,2 \\
\hline Oktober & 3,12 \\
\hline November & 3,09 \\
\hline Desember & 2,9 \\
\hline
\end{tabular}

Sumber: Data primer yang diolah,2015

Dari data diatas dapat dilihat bahwa terjadi penurunan kinerja karyawan yang menurun mulai bulan September sampai bulan Desember 2015. Terjadi kenaikan kinerja pada bulan Juli menuju bulan Agustus dari 3,52 ke 3,59. Namun pada bulan Agustus ke bulan September terjadi penurunan dari 3,59 menurun menjadi 3,20. Hal ini terus berlanjut pada bulan Oktober yang menurun menjadi 3,12 dan puncaknya pada bulan Desember kinerja karyawan menurun sampai 2,90. Penurunan ini disebabkan karena kinerja bagian pemasaran yang tidak mencapai target penjualan, sehingga fungsi lainnya ikut mengalami penurunan. Perusahaan yang bergerak dibidang pendistribusian keramik sehingga apabila kinerja pemasaran menurun maka hal itu akan berdampak secara keseluruhan.

Kotter dan Heskett (1992:9) menyatakan bahwa budaya organisasi yang kuat akan berpengaruh positif terhadap kinerja bisnis karena dapat memberikan motivasi luar biasa pada karyawan. Penelitian Sinha et al (2010) dari menunjukkan bahwa budaya organisasi berpengaruh positif terhadap motivasi. Penelitian ini sejalan dengan penelitian yang dilakukan Susanto dan Aisiyah (2010). Hal yang berbeda diungkapkan oleh Wildan (2010) yang menyatakan bahwa budaya organisasi tidak berpengaruh terhadap motivasi kerja karyawan.

Menurut Uno (2008:112) motivasi merupakan suatu dorongan atau proses yang dilakukan untuk menggerakkan seseorang agar perilakunya dapat diarahkan pada suatu tujuan tertentu.

Menurut Mangkunegara (2015:93) motivasi adalah kondisi yang menggerakkan karyawan agar mampu mencapai tujuan dari motifnya. Motivasi dapat menumbuhkan sense of belonging (rasa memiliki suatu organisasi) akhirnya dapat meningkatkan partisipasi dan komunikasi serta menumbuhkan empati atau kemampuan untuk menempatkan diri pada posisi orang lain. Dengan demikian karyawan akan lebih siap menerima dan melaksanakan perubahan-perubahan, termasuk alih teknologi dan alih ketrampilan baik dibidang teknik maupun bidang organisasi.

Penelitian Kesuma (2007) membuktikan bahwa motivasi berpengaruh positif terhadap kinerja karyawan Universitas Darwan Ali. Hal itu mungkin juga dapat terjadi pada PT. Rahmat Jaya Perkasa. Menurut personalia PT. Rahmat Jaya Perkasa, perusahaan memberikan motivasi baik berupa moral maupun berupa material. Perusahaan memberikan motivasi moral dengan mengkomunikasikan tugas yang diberikan, memberikan pengarahan maupun melakukan pengawasan. Sedangkan secara material perusahaan memberikan motivasi berupa kompensasi, penyediaan fasilitas ibadah, ruang kerja dan memberikan jaminan kerja (BPJS). Perusahaan mengharapkan dengan adanya motivasi ini dapat membuat karyawan lebih terdorong dalam bekerja sehingga kinerja karyawan akan naik.

Peningkatan kinerja juga dapat didasari oleh motivasi. Hal ini sejalan dengan penelitian yang dilakukan oleh Indraswari dan Djastuti (2014), Zameer et al (2014), Krisdiyanto (2010) serta Kesuma (2007) yang menyatakan motivasi berpengaruh secara positif terhadap kinerja dari seorang karyawan. dengan demikian dapat dikatakan bahwa manakala karyawan memiliki motivasi yang tinggi maka akan menghasilkan kinerja yang sesuai dengan keinginan organisasi. Namun penelitian dari Rahmayati dan Afandi (2014) menyatakan bahwa motivasi tidak berpengaruh terhadap kinerja karyawan.

Berdasarkan latar belakang, gap research dan fenomena diatas maka peneliti tertarik melakukan penelitian dengan judul "Pengaruh Budaya Organisasi Terhadap Kinerja Karyawan Melalui Motivasi PT. Rahmat Jaya Perkasa"

\section{KAJIAN PUSTAKA DAN PENGEMBANGAN HIPOTESIS}

Teori Budaya Organisasi

Menurut Wibowo (2012:481) budaya organisasi adalah norma-norma dan kebiasaan yang diterima sebagai suatu kebenaran oleh semua orang dalam organisasi. Budaya organisasi menjadi acuan bersama diantara manusia dalam melakukan interaksi organisasi.

Menurut Daniel R. Dennison dalam Riani (2011:7) budaya organisasi adalah nilai-nilai, keyakinan dan prinsipprinsip dasar yang merupakan landasan bagi system dan praktek-praktek manajemen serta perilaku yang meningkatkan dan menguatkan prinsip-prinsip tersebut.

Teori Kinerja Karyawan

Kinerja menurut Stoner (1978) dalam Tika (2014:121) mengemukakan bahwa kinerja adalah fungsi dari motivasi, kecakapan dan persepsi peranan.

Menurut Mangkunegara (2015:67) istilah kinerja berasal dari kata job performance atau actual performance (prestasi kerja atau prestasi sesungguhnya yang di capai oleh seseorang). Pengertian kinerja (prestasi) adalah hasil kinerja secara kualitas, kuantitas, dan ketepatan waktu yang dicapai oleh seorang karyawan dalam melaksanakan tugasnya sesuai dengan tanggung jawab yang diberikan kepadanya.

Teori Komitmen Organisasi

Menurut Fillmore H. Standford (1969) dalam Mangkunegara (2015:93) mendefinisikan "Motivation as an energizing condition of the organism that serves to direct that organism toward the goal of certain class".(Motivasi sebagai suatu kondisi yang menggerakkan manusia ke arah suatu tujuan tertentu).

Menurut Vroom dalam Purwanto (2006: 72), motivasi mengacu kepada suatu proses mempengaruhi pilihan-pilihan 
individu terhadap bermacam-macam bentuk kegiatan yang dikehendaki.

Menurut Uno (2008:112) motivasi merupakan suatu dorongan atau proses yang dilakukan untuk menggerakkan seseorang agar perilakunya dapat diarahkan pada suatu tujuan tertentu.

Dari teori-teori diatas dan tujuan penelitian maka berikut hipotesis yang akan diajukan dalam penelitian ini:

$\mathrm{H}_{1}$ = Diduga budaya organisasi berpengaruh terhadap kinerja karyawan pada PT. Rahmat Jaya Perkasa Sidoarjo.

$\mathrm{H}_{2}=$ Diduga motivasi berpengaruh terhadap kinerja karyawan pada PT. Rahmat Jaya Perkasa Sidoarjo.

$\mathrm{H}_{3}=$ Diduga budaya organisasi berpengaruh terhadap motivasi pada PT. Rahmat Jaya Perkasa Sidoarjo.

$\mathrm{H}_{4}=$ Diduga budaya organisasi berpengaruh terhadap kinerja karyawan melalui motivasi pada PT. Rahmat Jaya Perkasa Sidoarjo.

\section{METODE PENELITIAN}

Desain penelitian yang digunakan adalah kausalitas yang disusun untuk meneliti adanya hubungan sebab akibat antar variabel terdiri dari budaya organisasi, motivasi dan kinerja karyawan. Pendekatan kuantitatif digunakan dalam penelitian ini untuk menekankan hipotesis yang telah dirumuskan.

Sumber data yang digunakan merupakan data primer yang di dapatkan dari penyebaran kuisioner langsung pada karyawan PT.Rahmat Jaya Perkasa.

Populasi dan sampel dari penelitian ini adalah 42 orang karyawan PT.Rahmat Jaya Perkasa dan angket yang kembali sebanyak 42 kuesioner.

Variabel yang digunakan dalam penelitian yaitu: Budaya Organisasi sebagai variabel independen dengan pengertian keyakinan dan nilai-nilai organisasi yang diyakini dan dijiwai oleh seluruh anggotanya dalam melakukan pekerjaan sebagai cara yang tepat untuk memahami, memikirkan, dan merasakan terhadap masalah-masalah yang ada dalam perusahaan.

Indikator yang digunakan untuk mengukur budaya organisasi dalam penelitian mengacu pada budaya organisasi yang berada dalam PT.Rahmat Jaya Perkasa, yaitu :

1) Profesional : Keterampilan dan kecakapan yang dibutuhkan dalam kaitannya dengan profesi serta fungsi, tugas, dan kewajiban jabatan.

2) Integritas : Dapat dipercaya, jujur, konsisten dalam memahami dan keinginan untuk menyesuaikan diri dengan nilai-nilai dan kebijakan organisasi serta mematuhi etika profesi dan bisnis.

3) Inovasi : Kemampuan untuk mengembangkan ide, gagasan, pendekatan baru dan inovatif yang aplikatif untuk dapat melakukan pekerjaan lebih efektif dan efisien dalam rangka melakukan perubahan untuk perbaikan dan berani mengambil resiko.

4) Teamwork : Suatu bentuk kerja sama dalam melakukan suatu pekerjaaan yang dilakukan oleh beberapa orang dalam mencapai penyelesaian tugas terbaik.

5) Orientasi pelanggan : Memberikan pelayanan terbaik sesuai atau melebihi harapan pelanggan.

Kinerja karyawan sebagai variabel dependen dengan pengertian hasil kinerja secara kualitas, kuantitas, dan ketepatan waktu yang dicapai oleh seorang karyawan dalam melaksanakan tugasnya sesuai dengan tanggung jawab yang diberikan kepadanya. Mangkunegara (2015:67).

Indikator komitmen organisasi dalam penelitian sesuai dengan pendapat Mangkunegara (2015:75) mengemukakan sebagai berikut:

1) Kualitas ,merupakan tingkat sejauh mana proses atau hasil kegiatan mendekati kesempurnaan atau mendekati tujuan yang diharapkan. Kualitas diukur melalui ketepatan, ketelitian, keterampilan dan kebersihan dalam melakukan tugas.

2) Kuantitas,merupakan jumlah pekerjaan yang dihasilkan seberapa cepat dalam

3) Keandalan, dapat dipercaya dalam mengikuti instruksi,inisiatif, hati-hati dan kerajinan dalam melaksanakan perintah.

4) Sikap, merupakan cara berprilaku karyawan terhadap karyawan perusahaan lain, peekerjaan dan kerjasama.

Motivasi sebagai variabel intervening dengan pengertian motivasi merupakan suatu dorongan atau proses yang dilakukan untuk menggerakkan seseorang agar perilakunya dapat diarahkan pada suatu tujuan tertentu. Uno (2008:112).

Indikator moivasi dalam penelitian mengancu pada tanggung jawab, prestasi, pengembangan diri dan kemandirian yang dikemukakan oleh Uno (2008:112).

Teknik analisis data yang digunakan adalah Partial Least Square. Sebelum analisis Partial Least Square dilakukan pengujian validitas dan reliabilitas dengan tujuan mengetahui apakah item pernyataan tersebut valid dan reliabel, lalu dilakukan analisis deskriptif untuk memudahkan pembaca untuk mengetahui data yang disajikan.

\section{HASIL DAN PEMBAHASAN}

1. Karakteristik responden berdasarkan jenis kelamin

Populasi PT. Rahmat Jaya Perkasa adalah 42 karyawan, dari 42 angket yang dibagikan semua angket tersebut kembali. Dari 42 responden yang menjawab angket yang telah disediakan, dapat diketahui jenis kelamin para responden yang ditunjukkan pada tabel berikut ini:

Tabel 4.2 Karakteristik Responden Berdasarkan Jenis Kelamin

\begin{tabular}{|c|c|c|c|}
\hline No & Jenis Kelamin & Jumlah & Presentasi \\
\hline 1. & Laki-Laki & 15 & 35,8 \\
\hline 2. & Perempuan & 27 & 64,2 \\
\hline \multicolumn{2}{|c|}{ Total } & 47 & 100 \\
\hline
\end{tabular}

Sumber: SPSS 18(2016)

Berdasarkan tabel 4.2 di atas, diketahui bahwa 47 responden karyawan dijadikan subyek penelitian, 27 orang $(64,28 \%)$ adalah responden berjenis perempuan dan responden yang berjenis kelamin laki-laki ada 15 orang
$(35,28)$. Hasil tersebut menunjukkan bahwa mayoritas karyawan PT. Rahmat Jaya Perkasa berjenis kelamin perempuan.

2. Karakteristik responden berdasarkan lama bekerja 
BISMA - Bisnis dan Manajemen -Volume 9 No. 1 Oktober 2016

Dari 42 responden yang menjawab angket yang telah ditunjukkan disediakan, dapat diketahui lama bekerja responden yang

pada

tabel

berikut

ini: 
Tabel 4.3 Karakteristik Responden Berdasarkan Lama Bekerja

\begin{tabular}{|c|c|c|c|c|c|}
\hline \multicolumn{6}{|c|}{ Lama_bekerja } \\
\hline & & Frequency & Percent & Valid Percent & $\begin{array}{c}\text { Cumulative } \\
\text { Percent }\end{array}$ \\
\hline \multirow[t]{5}{*}{ Valid } & $>3$ tahun & 7 & 16,7 & 16,7 & 16,7 \\
\hline & $4-6$ tahun & 15 & 35,7 & 35,7 & 52,4 \\
\hline & $7-10$ tahun & 13 & 31,0 & 31,0 & 83,3 \\
\hline & $>10$ tahun & 7 & 16,7 & 16,7 & 100,0 \\
\hline & Total & 42 & 100,0 & 100,0 & \\
\hline
\end{tabular}

Sumber: SPSS 18 (2016)

Berdasarkan tabel 4.3 di atas jumlah responden berdasarkan lama bekerja dalam penelitian ini, lama bekerja $\leq$ 3 tahun sebanyak 7 karyawan $(16,7 \%)$, lama bekerja antara 46 tahun sebanyak 15 karyawan (35,7\%), lama bekerja 7-10 sebanyak 13 karyawan (31\%), dan yang terakhir lama bekerja $>10$ tahun sebanyak 7 karyawan $(21,43 \%)$.
3. Karakteristik responden berdasarkan pendidikan

Dari 42 responden yang menjawab angket yang telah disediakan, dapat diketahui kisaran latar belakang pendidikan responden yang ditunjukkan pada tabel berikut ini

Tabel 4.4 Karakteristik Responden Berdasarkan Pendidikan

\begin{tabular}{|ll|r|r|r|r|}
\multicolumn{7}{|c|}{ Pendidikan } \\
\hline Valid & SMA & Frequency & Percent & Valid Percent & $\begin{array}{c}\text { Cumulative } \\
\text { Percent }\end{array}$ \\
& D3 & 10 & 61,9 & 61,9 & 61,9 \\
& S1 & 26 & 14,8 & 23,8 & 85,7 \\
& Total & 42 & 100,0 & 14,3 & 100,0 \\
\hline
\end{tabular}

Sumber: SPSS 18 (2016)

Berdasarkan tabel 4.4 di atas jumlah responden berdasarkan pendidikan dalam penelitian ini, SMA sederajat 26 karyawan $(61,9 \%)$, Diploma sebanyak 10 karyawan $(23,8)$ sarjana (S1) sebanyak 6 karyawan $(14,3)$.
4. Karakteristik responden berdasarkan usia responden Dari 47 responden yang menjawab angket yang telah disediakan, dapat diketahui kisaran latar belakang pendidikan responden yang ditunjukkan pada tabel berikut ini

Tabel 4.5 Karakteristik Responden berdasarkan umur

\begin{tabular}{|ll|r|r|r|r|}
\hline \multicolumn{1}{|c|}{ Usia } \\
\hline & Frequency & Percent & Valid Percent & $\begin{array}{c}\text { Cumulative } \\
\text { Percent }\end{array}$ \\
\hline Valid & $>20$ tahun & 1 & 2,4 & 2,4 & 2,4 \\
& $21-25$ tahun & 2 & 4,8 & 4,8 & 7,1 \\
& $26-30$ tahun & 8 & 19,0 & 19,0 & 26,2 \\
& $>30$ tahun & 31 & 73,8 & 73,8 & 100,0 \\
Total & 42 & 100,0 & 100,0 & \\
\hline
\end{tabular}

Sumber: SPSS (2016)

Berdasarkan table 4.5 di atas jumlah responden berdasarkan umur dalam penelitian ini, <20 tahun sebanyak 1 karyawan (2,4\%), 21-25 tahun sebanyak 2 karyawan $(4,8 \%)$, 26-30 tahun sebanyak 8 karyawan $(19,0 \%),>30$ tahun sebanyak 31 karyawan $(73,8 \%)$.

Hasil Statistik Rata-Rata Budaya Organisasi

Hasil statistik rata - rata budaya organisasi menunjukkan bahwa penerapan budaya organisasi PT. Rahmat Jaya Perkasa dalam indikator profesionalitas dalam kategori tinggi. Hal tersebut dibuktikan dari nilai rata- rata sebesar 4,29\% dengan keterangan 34 pernyataan sangat setuju dan 39 pernyataan setuju, sedangkan jawaban netral, tidak setuju dan sangat tidak setuju.

Kemudian untuk hasil indikator profesional memiliki nilai rata - rata yang sama tingginya dengan inovasi sebesar $4,29 \%$. Hal ini dibuktikan dari pernyataan pada 36 pernyataan sangat setuju dan 38 pernyataan setuju, sedangkan jawaban netral, tidak setuju dan sangat tidak setuju hanya sebagian kecil responden yang menjawab. 
Ketiga indikator lain dalam budaya organisasi yaitu berkategori tinggi berturut-turut integritas, teamwork dan orientasi pelanggan dengan nilai 4,24, 4,19, dan 3,98 berturutturut.

\section{Kinerja Karyawan}

Hasil statistik rata - rata kinerja karyawan menunjukkan bahwa kinerja karyawan perusahaan dalam indikator kualitas termasuk dalam kategori tinggi. Nilai rata - ratanya adalah 4,00 dengan 38 pernyataan setuju, 27 pernyataan sangat setuju, dan sedikit terdapat pernyataaan netral, pernyataan tidak setuju maupun sangat tidak setuju.

Kemudian kuantitas terhadap pekerjaan itu sendiri memiliki nilai rata - rata tidak jauh berbeda sama tinggi sebesar 4,19. Keterangannya yaitu 31 pernyataan setuju, 39 pernyataan sangat setuju dan sedikit terdapat pernyataan netral, pernyataan tidak setuju maupun sangat tidak setuju.
Indikator selanjutnya memiliki nilai yang sama tinggi berturut - turut yaitu sikap dan kenadalan dengan nilai rata rata 4,24 dan 4,17 .

\section{Motivasi}

Hasil statistik rata - rata motivasi menunjukkan bahwa indikator pengembangan diri dalam kategori tertinggi dengan nilai rata - rata 4,33.

Kemudian rata - rata tertinggi selanjutnya adalah kemandirian dengan nilai 4,24. Nilai dari tanggung jawab dalam kategori yang tinggi dengan rata - rata sebesar 4,00 serta nilai dari prestasi dalam kategori yang tinggi dengan rata - rata sebesar 3,98.

\section{Uji Validitas}

Uji validitas digunakan untuk menentukan apakah indikator dinyatakan valid dan dapat mengukur variabel yang diteliti. Uji validitas dilakukan dengan bantuan software smartPLS

Tabel 4.10 Outer Loadings Variabel Budaya Organisasi

\begin{tabular}{|c|c|c|}
\hline Item $(\mathrm{X})$ & Loading Factor & Keterangan \\
\hline $\mathrm{X} 1$ & 0.739 & Valid \\
\hline $\mathrm{X} 2$ & 0.756 & Valid \\
\hline $\mathrm{X} 3$ & 0.753 & Valid \\
\hline $\mathrm{X} 4$ & 0.764 & Valid \\
\hline $\mathrm{X} 5$ & 0.786 & Valid \\
\hline
\end{tabular}

Sumber: Output SmartPLS 3.0 (2016)

Berdasarkan tabel 4.10 di atas, dapat diketahui bahwa melebihi 0,6sehingga item-item variabel tersebut dikatakan loading factor dari masing-masing item budaya organisasi valid.

Tabel 4.11 Outer Loadings Variabel Kinerja Karyawan

\begin{tabular}{|c|c|c|}
\hline Item(Z) & Loading factor & Keterangan \\
\hline Y1 & 0.838 & Valid \\
\hline Y2 & 0.830 & Valid \\
\hline Y3 & 0.803 & Valid \\
\hline Y4 & 0.648 & Valid \\
\hline
\end{tabular}

Sumber: Output SmartPLS 3.0 (2016)

Berdasarkan tabel 4.11 di atas, dapat diketahui bahwa loading factor dari masing-masing item kinerja lebih besar dari 0.60 sehingga item-item variabel tersebut dikatakan valid.

Tabel 4.12 Outer Loadings Variabel Motivasi

\begin{tabular}{|c|c|c|}
\hline Item(Z) & Loading factor & Keterangan \\
\hline $\mathrm{Z} 1$ & 0.740 & Valid \\
\hline $\mathrm{Z} 2$ & 0.820 & Valid \\
\hline $\mathrm{Z} 3$ & 0.637 & Valid \\
\hline $\mathrm{Z} 4$ & 0.657 & Valid \\
\hline \multicolumn{3}{|c|}{ Sumber: Output SmartPLS 3.0 (2016) } \\
\hline
\end{tabular}

Dari tabel 4.12 diatas menunjukkan outer loading dari masing masing item pernyataan motivasi lebih besar dari 0,60.

Berdasarkan tabel 4.10, 4.11 dan 4.12 tampak bahwa semua outer loading di atas 0,60 . Hal ini dapat disimpulkan bahwa variabel-variabel di atas mempunyai convergent validity yang baik.

\section{Uji Reliabilitas}

Composite reliability ini digunakan untuk menguji nilai reliabilitas dari setiap blok indikator yang mengukur sebuah konstruk. Konstruk dinyatakan reliable jika nilai composite reliability di atas 0,70 . Berikut ini adalah hasil perhitungan composite reliability pada tiap variabel.

Tabel 4.14 Hasil Composite Reability

\begin{tabular}{|c|c|}
\hline & Composite Reliability \\
\hline Budaya Organisasi & 0.872 \\
\hline
\end{tabular}




\begin{tabular}{|c|c|}
\hline Kinerja Pegawai & 0.863 \\
\hline Motivasi Pegawai & 0.807 \\
\hline Sumber Owtput Smat
\end{tabular}

Sumber :Output SmartPLS 3.0 (2016)

Berdasarkan tabel 4.14 terlihat nilai composite reliability untuk semua variabel lebih besar dari 0,70. Dengan demikian model variabel tersebut telah memenuhi composite reliability atau memiliki reliabilitas yang baik.

\section{Hasil R-Square (Inner Model)}

Berikut ini merupakan hasil dari pengaruh budaya organisasi terhadap kinerja melalui motivasi sebagai variabel mediasi pada PT.Rahmat Jaya Perkasa Sidoarjo , dihasilkan nilai koefisien determinan ( $R$-Square).

Tabel 4.15 Hasil $R$-Square

\begin{tabular}{|c|c|}
\hline & R-Square \\
\hline Budaya Oganisasi (X) & - \\
\hline Kinerja Pegawai (Y) & 0.625 \\
\hline Motivasi Pegawai (Z) & 0.490 \\
\hline
\end{tabular}

Sumber :Output SmartPLS 3.0 (2016)

Pada tabel 4.15 di atas, model pengaruh budaya organisasi terhadap kinerja pegawai memberikan nilai $R$ Square sebesar 0,625 yang dapat diinterpretasikan bahwa variabilitas konstruk kinerja pegawai yang dapat dijelaskan oleh variabilitas konstruk budaya organisasi sebesar $62,5 \%$ sedangkan 46,5\% dijelaskan oleh variabel lain di luar yang diteliti.

Selanjutnya model pengaruh budaya organisasi terhadap motivasi kerja memberikan nilai $R$-Square sebesar 0,490 yang dapat diinterpretasikan bahwa variabilitas konstruk motivasi kerja yang dapat dijelaskan oleh variabilitas konstruk budaya organisasi sebesar $49 \%$ sedangkan $51 \%$ dijelaskan oleh variabel lain di luar yang diteliti.

\section{Hasil Uji T (Signifikansi)}

Tahapan ini bertujuan untuk mengetahui ada atau tidaknya pengaruh yang signifikan antar variabel. Suatu pengaruh antar variabel dikatakan signifikan apabila nilai $t$ hitung lebih besar dari 1,96 atau $\mathrm{P}$ value lebih kecil dari 0,05.

Tabel 4.16 Hasil Path Coefficients

\begin{tabular}{|c|c|c|c|c|}
\hline $\begin{array}{c}\text { Hubungan antar } \\
\text { variabel }\end{array}$ & $\begin{array}{c}\text { Original } \\
\text { Sample }(\mathbf{O})\end{array}$ & T-statistics & Keterangan & Kesimpulan \\
\hline $\begin{array}{c}\text { Budaya Organisasi > } \\
\text { Kinerja pegawai }\end{array}$ & 0.475 & 4.170 & Signifikan & $\begin{array}{c}\text { Hipotesis } \\
\text { diterima }\end{array}$ \\
\hline $\begin{array}{c}\text { Budaya Organisasi }> \\
\text { Motivasi Kerja }\end{array}$ & 0.700 & 10.461 & Signifikan & $\begin{array}{c}\text { Hipotesis } \\
\text { diterima }\end{array}$ \\
\hline $\begin{array}{c}\text { Motivasi Kerja > } \\
\text { Kinerja Pegawai }\end{array}$ & 0.382 & 3.076 & Signifikan & $\begin{array}{c}\text { Hipotesis } \\
\text { diterima }\end{array}$ \\
\hline
\end{tabular}

Sumber :Output SmartPLS 3.0 (2016)

Hasil dari tabel 4.16 di atas untuk pengaruh budaya organisasi terhadap kinerja pegawai menunjukkan nilai koefisien parametersebesar 0.475 . Koefisien tersebut bertanda positif yang berarti apabila semakin tinggi budaya organisasi maka semakin tinggi kinerja pegawai, begitu juga sebaliknya.Sedangkan nilai T-statistic sebesar 4.170 lebih besar dari 1.96.Hal ini menunjukkan adanya pengaruh yang signifikan antara variabel budaya organisasi terhadap kinerja pegawai.

Hasil dari tabel 4.16 juga dapat disimpulkan bahwa pengaruh budaya organisasi terhadap motivasi kerja menunjukkan nilai koefisien parametersebesar 0.700.Koefisien tersebut bertanda positif yang berarti apabila semakin tinggi budaya organisasi maka semakin tinggi motivasi kerja, begitu juga sebaliknya.Sedangkan nilai $T$ - statistic sebesar 10.461 lebih besar dari 1.96.Hal ini menunjukkan adanya pengaruh yang signifikan variabel budaya organisasi terhadap motivasi kerja.

Hasil dari tabel 4.16 juga dapat disimpulkan bahwa pengaruh motivasi kerja dengan kinerja pegawai, menunjukkan nilai koefisien parametersebesar 0.382.Koefisien tersebut bertanda positif yang apabila semakin tinggi motivasi kerja maka semakin tinggi kinerja pegawai begitu juga sebaliknya.Sedangkan nilai T-statistic sebesar 3.076 lebih besar dari 1.96. Hal ini menunjukkan adanya pengaruh yang signifikan antara variabel motivasi kerja terhadap kinerja pegawai.

Dalam penelitian ini, dapat dilihat besarnya koefisien pengaruh langsung dan tidak langsung antar variabel dalam tabel berikut: 
BISMA - Bisnis dan Manajemen -Volume 9 No. 1 Oktober 2016

Tabel 4.17 Pengaruh Langsung dan Tidak Langsung

\begin{tabular}{|c|c|c|c|c|}
\hline Pengaruh Antar Variabel & $\begin{array}{c}\text { Original } \\
\text { Sampel (O) }\end{array}$ & $\begin{array}{c}\text { T Statistics } \\
\text { (IO/STERRI) }\end{array}$ & T-table & Kesimpulan \\
\hline $\begin{array}{c}\text { Budaya Organisasi }> \\
\text { Kinerja Pegawai }\end{array}$ & 0.475 & 4.170 & $\geq 1,96$ & \\
\hline $\begin{array}{c}\text { Budaya Organisasi } \\
\text { Motivasi Kerja> Kinerja } \\
\text { Pegawai }\end{array}$ & 0.267 & 2,773 & $\geq 1,96$ & Hipotesis ditolak \\
\hline
\end{tabular}

Sumber: Result smartPLS 3.0

Dari tabel 4.17 dapat diketahui bahwa besarnya koefisien pengaruh langsung antara budaya organisasi terhadap kinerja pegawai (0.475) lebih besar daripada pengaruh tidak langsung antara budaya organisasi terhadap kinerja pegawai melalui motivasi pegawai $(0,267)$.Hal ini menunjukkan bahwa motivasi pegawai tidak memediasi atau menjadi variabel intervening dalam pengaruh budaya organisasi terhadap kinerja pegawai.

\section{Pengaruh Budaya Organisasi Terhadap Kinerja Karyawan}

Budaya organisasi yang terjadi di PT. Rahmat Jaya Perkasa termasuk dalam kategori tinggi yaitu mencapai ratarata 4,20. Rata-rata tertinggi ditunjukkan pada indicator profesional dan inovasi yaitu sebesar 4,29 dengan kategori tinggi. Hal ini menunjukkan karyawan memiliki keinginan dalam melakukan sebuah inovasi yang tinggi disertai dengan profesional dalam bekerja.

Budaya organisasi PT. Rahmat Jaya Perkasa dibentuk oleh para pemimpin organisasi, nilai-nilai yang telah ada dalam anggota organisasi, dikomunikasikan melalui berbagai media, baik dengan komunikasi secara lisan maupun dengan tulisan. Media yang menggunakan komunikasi secara lisan, seperti pertemuan tatap muka, dan workshop. Sedangkan media yang menggunakan media tulisan, seperti poster yang berada di dinding kantor PT.Rahmat Jaya Perkasa.

Budaya organisasi yang sudah ditetapkan oleh PT. Rahmat Jaya Perkasa tentunya dilaksanakan dengan baik oleh pegawai sesuai dengan petunjuk dan arahan yang diberikan oleh perusahaan. Upaya perusahaan dalam meningkatkan sumber daya manusia dilakukan dengan adanya evaluasi secara berkala dan pembelajaran ke pusat perusahaan bagi pegawai baru agar sesuai dengan standart perusahaan.

Budaya organisasi yang berada dalam perusahaan terdiri dari lima nilai, profesional, integritas, inovasi, teamwork dan orientasi pelanggan. Budaya profesional dalam perusahaan PT. Rahmat Jaya Perkasa memiliki rata-rata yang tinggi menurut tanggapan responden yaitu 4,29 sehingga dapat disimpulkan pelaksanaan budaya ini terlaksana dengan baik. Dalam pelaksanaan budaya profesionalitas memiliki regulasi tersendiri. Regulasi tersebut berada dalam buku pedoman mengenai prosedur dan kedisiplinan dalam masing-masing divisi. Sayangnya, regulasi mengenai budaya organisasi tidak diletakkan pada buku pedoman.

Dalam pelaksanaan budaya organisasi profesionalitas yang berada dalam perusahaan terlihat seperti dari daftar absensi yang menunjukkan bahwa karyawan tepat waktu dalam melaksanakan pekerjaannya. Selain ketepatan waktu, profesionalitas karyawan terlihat saat melaksanakan pekerjaannya. Hal ini terlihat pada saat proses pemesanan barang dari pelanggan melalui sales. Pemesanan melalui sales di laporkan melalui telemarketing lalu oleh telemarketing di proses agar barang segera di kirim oleh bagian operasional. Dalam pelaksanaannya karyawan menjalankan tanggung jawabnya dengan baik. Berdasarkan hasil wawancara 11 agustus 2016 hal ini terlihat dari berkurangnya barang yang kembali dari pengiriman dan komplain pelanggan.

Budaya integritas dalam perusahaan PT. Rahmat Jaya Perkasa memiliki rata-rata tanggapan responden yang tinggi yaitu 4,24 hal ini menunjukkan bahwa budaya telah terlaksana dengan baik dari berbagai divisi. Karyawan patuh terhadap peraturan yang ada. Dalam divisi keuangan, terjadi kesamaan antara jumlah dana masuk dan keluar, hal ini menandakan bahwa divisi keuangan telah menanamkan nilai kejujuran yang ada dalam perusahaan. Namun, masih ada yang melanggar aturan dalam perusahaan. Berdasarkan hasil wawancara pada tanggal 11 agustus 2016, ada 2 sampai 3 orang yang melanggar aturan perusahaan.

Budaya inovasi dalam perusahaan PT. Rahmat Jaya Perkasa memiliki rata-rata tanggapan responden yang tinggi yaitu 4,29 hal ini menunjukkan bahwa budaya telah terlaksana dengan baik. budaya inovasi dalam perusahaan terlihat dari bagian pemasaran yaitu Telemarketing dahulu perusahaan hanya menggunakan bagian telemarketing sebagai penerima order dari sales, namun sekarang bagian telemarketing selain bertugas mencatat pesanan barang yang dikirimkan sales, menerima order dari pelanggan secara langsung, mencari pangsa pasar baru, serta mengenai status pengiriman barang.

Budaya teamwork memiliki rata-rata tanggapan responden yang tinggi yaitu 4,19 hal ini menunjukkan bahwa budaya telah terlaksana dengan baik dari berbagai divisi. Budaya ini dilakukan pada saat karyawan membutuhkan bantuan karyawan lain, seperti pada divisi pemasaran. Hal ini terjadi pada saat sales ingin menjual produk disuatu lokasi, namun belum mengerti watak dan sifat konsumen didaerah tersebut karyawan yang pernah menempati daerah tersebut akan memberi arahan perilaku agar tidak terjadi salah paham. Selain itu, karyawan akan saling membantu dalam hal penginformasian informasi-informasi baru mengenai stok produk.

Budaya orientasi pelanggan memiliki rata-rata tanggapan responden yang tinggi yaitu 3,98 hal ini menunjukkan bahwa budaya telah terlaksana dengan baik. Dalam pelaksanaan budaya ini, pelanggan dapat melakukan komplain barang melalui telepon dan pelanggan dapat memesan barang melalui telepon melalui telemarketing.

Berdasarkan uji yang telah dilakukan maka diketahui bahwa budaya organisasi memberikan pengaruh positif signifikan terhadap kinerja pegawai. Hal ini dapat ditunjukkan dengan nilai T-statistic 4.170 lebih besar dari 1,96. Terdapatnya pengaruh positif budaya organisasi terhadap 
kinerja pegawai ditunjukkan pada nilai koefisien parameter yang menunjukkan arah positif yaitu 0.475 yang berarti semakin tinggi budaya organisasimaka semakin tinggi kinerja pegawai PT.Rahmat Jaya Perkasa.

Dengan adanya penerapan budaya organisasi pada PT. Rahmat Jaya Perkasa, para karyawan dalam aktivitas kerja sehari-hari dapat memberikan pengaruh dalam peningkatan kinerja para karyawan, dengan dibuktikan ketika perusahaan melakukan pengarahan dan rapat evaluasi dalam rangka menigkatkan profesional dan intgritas karyawan, dan memicu inovasi-inovasi terbaru serta membangun jaringan teamwork guna mendukung tercapainya tujuan bersama.

Pengaruh budaya organisasi terhadap kinerja pegawai PT. Rahmat Jaya Perkasa memberikan nilai $R$-Square sebesar 0.625 yang dapat diinterpretasikan bahwa variabilitas konstruk kinerja pegawai yang dapat dijelaskan oleh variabilitas konstruk budaya organisasisebesar 62,5\%. Hasil penelitian ini didukung oleh hasil penelitian Indrawati dan Djastuti (2012) menyatakan bahwa budaya organisasi berpengaruh positif signifikan terhadap kinerja karyawan. Hasil penelitian di atas juga mendukung hasil penelitian Krisdiyanto (2011) menyebutkan bahwa budaya organisasi berpengaruh positif signifikan terhadap kinerja karyawan.

\section{Pengaruh Budaya Organisasi Terhadap Motivasi}

Motivasi kerja karyawan kerja PT. Rahmat Jaya Perkasa termasuk dalam kategori tinggi yaitu mencapai rata-rata 4,15. Nilai tertinggi pada motivasi kerja ditunjukkan dengan ratarata mencapai 4,33 pada indikator pengembangan diri. Hal ini menunjukkan bahwa bahwa ketika karyawan dalam bekerja selalu berusaha mengembangkan potensi dan kemampuannya dalam bekerja.

Sikap tanggung jawab pada karyawan PT. Rahmat Jaya Perkasa memiliki rata-rata tanggapan responden yang tinggi yaitu 3,98 hal ini menunjukkan bahwa motivasi yang berasal tanggung jawab termasuk tinggi. tanggung jawab tercemin pada saat karyawan melaksanakan tugasnya. Seperti, bagian keuangan yang seharusnya menyelesaikan laporan dalam satu bulan mengenai pembayaran utang dan piutang namun, pelaksanaan tugas tersebut tidak mencapai target satu bulan sehingga pelaksanaan tanggung jawab tidak berjalan dengan lancar.

Keinginan dalam berprestasi pada karyawan PT. Rahmat Jaya Perkasa memiliki rata-rata tanggapan responden yang tinggi yaitu 4,14 hal ini menunjukkan bahwa motivasi yang berasal dari prestasi termasuk tinggi. Salah satu karyawan dalam wawancara tanggal 11 agustus 2016 salah satu cara mencapai prestasi tersebut yang dilakukan Bekerja sesuai dengan target yang ditetapkan oleh perusahaan selain itu menaati seluruh peraturan yang berada didalam perusahaan.

Sikap pengembangan diri memiliki rata-rata tanggapan responden yang tinggi yaitu 4,33 hal ini menunjukkan bahwa motivasi yang berasal dari pengembangan diri termasuk tinggi. Sikap pengembangan diri yang tercermin pada karyawan dibuktikan ketika karyawan dalam melakukan aktivitas kerja selalu bekerja sesuai kemampuannya sehingga selesai pada waktu yang telah ditentukan atasan. Dalam pelaksanaannya seperti adanya penghargaan pada karyawan berprestasi, dan perhargaan pada tim. Penghargaan pada karyawan berprestasi dilakukan setahun sekali dengan penghargaan berupa sertifikat, serta bonus gaji sekitar $10 \%$.
Penghargaan pada tim berupa liburan bersama bila mencapai target tertentu.

Sikap kemandirian memiliki rata-rata tanggapan yang tingi yaitu 4,29. Hal ini ditunjukkan dengan adanya tugas yang terlaksana dengan mengerjakan tugas secara sendirisendiri sehingga tugas telah terlaksana dengan baik. Kemandirian dalam PT.Rahmat Jaya Perkasa seperti pada divisi operasional yang menyelesaikan pengiriman barang dengan baik, dan mengambil keputusan mengenai pengiriman seperti ekspedisi barang yang akan di gunakan atau mengenai keterlambatan pengiriman yang diakibatkan oleh kecelakaan.

Berdasarkan uji yang telah dilakukan maka diketahui bahwa budaya organisasi memberikan pengaruh positif signifikan terhadap motivasi kerja. Hal tersebut dapat ditunjukkan dengan nilai T-statistic 10.461 lebih besar dari 1,96. Terdapatnya pengaruh positif budaya organisasi terhadap motivasi kerjaditunjukkan pada nilai koefisien parameter yang menunjukkan arah positif 0.700 yang berarti semakin tinggi budaya organisasi maka semakin tinggi motivasi kerjaPT. Rahmat Jaya Perkasa.

Dengan adanya penerapan budaya organisasi pada PT. Rahmat Jaya Perkasa, para karyawan dalam aktivitas kerja sehari-hari dapat memberikan pengaruh dalam peningkatan motivasi kerjakaryawan, dengan dibuktikan ketika perusahaan melakukan pengarahan dengan mensosialisasikan budaya profesionalitas, integritas, inovasi, teamwork dan orientasi pelanggan pada pegawai, maka dalam melakukan aktivitas kerja karyawan selalu tanggung jawab, teliti dan selesai pada waktu yang telah ditentukan atasan. Menurut Riani (2011:9) budaya organisasi merupakan pemberi semangat bagi para anggota organisasi. Hal ini sejalan dengan pendapat Sutrisno (2011:2) budaya yang kuat dan positif sangat berpengaruh kuat terhadap organisasi salah satunya adalah pengarahan perilaku dan kinerja organisasi. Jadi budaya organisasi yang kuat akan menjadi motivator yang kuat juga bagi PT.Rahmat Jaya Perkasa.

Pengaruh budaya organisasi terhadap motivasi kerja PT.Rahmat Jaya Perkasa memberikan nilai R-Squared sebesar 0,490 yang dapat diinterpretasikan bahwa variabilitas konstruk motivasi kerja yang dapat dijelaskan oleh variabilitas konstruk budaya organisasisebesar 49\%. Hasil penelitian ini didukung oleh hasil penelitian Sinha et al (2010) yang menyatakan bahwa budaya organisasi berpengaruh positif signifikan terhadap motivasi kerja. Hasil penelitian ini juga mendukung hasil penelitian Susanto dan Aisiyah (2010) juga menyatakan bahwa budaya organisasi berpengaruh positif signifikan terhadap motivasi kerja pegawai.

\section{Pengaruh Motivasi Terhadap Kinerja Karyawan}

Kinerja pegawai yang terjadi di PT. Rahmat Jaya Perkasa termasuk dalam kategori tinggi yaitu mencapai rata-rata 4,15. Nilai tersebut termasuk katagori tinggi. Nilai tertinggi ditunjukkan dengan rata-rata mencapai 4,24 pada indikator sikap dengan kategori tinggi.

Nilai terendah pada kinerja pegawai ditunjukkan dengan rata-rata mencapai 4,00 pada indikator kualitas. Hal ini dibuktikan bahwa walaupun pekerjaan pegawai telah sesuai target namun kualitas dari pekerjaan tersebut belum tentu sesuai dengan keinginan perusahaan seperti pada pekerjaan yang mengharuskan perhitungan stok barang, pekerjaan tersebut sesuai target terselesaikan namun tidak menutup 
kemungkinan adanya kesalahan perhitungan stok barang tersebut. Dalam meningkatan kinerja pegawai terutama pada indikator kualitas dalam ketelitian dalam mengerjakan tugas, yaitu dengan mengadakan pelatihan pendalaman keterampilan profesi dari pegawai senior ataupun dari profesional yang menguasai bidang tersebut.

Indikator kuantitas pada variabel kinerja pegawai memiliki rata-rata yang tinggi mencapai 4,19 . Hal ini terlihat pada saat karyawan menyelesaikan seluruh pekerjaan, contohnya divisi pemasaran yang menyelesaikan rekapitulasi data pelanggan beserta pemesanan barang, data tersebut harus selesai pada hari itu juga agar bisa segera diproses oleh divisi operasional.

Indikator sikap pada variabel kinerja pegawai ditunjukkan dengan rata-rata mencapai 4,24. Hal ini tercermin pada pegawai bagian pemasaran yang mempunyai kemampuan berinteraksi dan berkomunikasi yang baik dalam menghadapi pelanggan yang mengurusi bagian penjualan hingga barang tersebut sampai pada pelanggan, lalu pegawai juga bersedia menerima saran dan keluhan para pelanggan dengan ramah, selain itu juga selalu berpenampilan rapi dan bersih.

Indikator keandalan pada variabel kinerja pegawai ditunjukkan dengan rata-rata mencapai 4,17. Hal ini berarti pegawai bisa diandalkan untuk mengerjakan dan menyelesaikan pekerjaannya dengan tepat. Dalam divisi keuangan, karyawan diharuskan untuk memahami applikasi yang memudahkan dalam perhitungan keuangan baik pembukuan ataupun mengenai perpajakan. Dalam pelaksanaanya karyawan pada divisi keuangan memahami dengan baik applikasi yang yang ada sehingga lebih mudah dalam mengerjakan laporan keuangan yang berada dalam perusahaan.

Berdasarkan uji yang telah dilakukan maka diketahui bahwa motivasi kerja memberikan pengaruh positif dan signifikan terhadap kinerja pegawai.Hal tersebut dapat ditunjukkan dengan nilai T-statistic 3.076 lebih besar dari 1,96. Terdapatnya pengaruh positif motivasi kerja terhadap kinerja pegawai ditunjukkan pada nilai koefisien parameter yang menunjukkan arah positif 0.382 yang berarti semakin tinggi motivasi kerja maka semakin tinggi kinerja pegawai PT. Rahmat Jaya Perkasa.

Dengan adanya motivasi yang tinggi, kinerja pegawai PT. Rahmat Jaya Perkasa juga meningkat. Namun karena kualitas yang dimiliki oleh pekerja tidak terlalu tinggi, dibutuhkan motivasi untuk meningkatkannya. Hal ini sejalan dengan penelitian yang dilakukan oleh Indraswari dan Djastuti (2014), Zameer et al (2014), Krisdiyanto (2010) serta Kesuma (2007) yang menyatakan motivasi berpengaruh secara positif terhadap kinerja dari seorang karyawan. dengan demikian dapat dikatakan bahwa manakala karyawan memiliki motivasi yang tinggi maka akan menghasilkan kinerja yang sesuai dengan keinginan organisasi.

\section{Pengaruh Budaya Organisasi Terhadap Kinerja} Karyawan Melalui Motivasi Sebagai Variabel Intervening

Dari hasil uji pengaruh langsung dan tidak langsung yang ditunjukkan dalam tabel 4.13, dapat diketahui bahwa besarnya koefisien pengaruh langsung antara budaya organisasi terhadap kinerja pegawai $(0,475)$ lebih besar daripada pengaruh tidak langsung antara budaya organisasi dengan kinerja pegawai melalui motivasi kerja $(0,267)$. Hal ini menunjukkan motivasi kerja bukan merupakan variabel intervening atau tidak memediasi pengaruh antara budaya organisasi terhadap kinerja pegawai.Pengaruh budaya organisasi terhadap kinerja pegawai PT. Rahmat Jaya Perkasa merupakan pengaruh langsung tanpa melalui motivasi kerja.

Pengaruh langsung motivasi kerja yang tidak signifikan terhadap kinerja pegawai inilah yang menyebabkan variabel motivasi kerja bukan sebagai variabel mediasi atau intervening dari pengaruh budaya organisasi terhadap kinerja pegawai. Hal ini didasari oleh faktor dari motivasi menurut Abraham Maslow, merupakan kebutuhan akan penghargaan diri dan pengakuan serta penghargaan tidak didukung dengan baik melalui jenjang karir yang meningkat apabila mengalami pencapaian tertentu. Sehingga, apabila menginginkan motivasi yang dapat memotivasi karyawan perusahaan seharusnya menambah jenjang karir yang berada dalam perusahaan. Hasil penelitian ini didukung oleh penelitian Moerdani (2010) yang menyatakan bahwa motivasi kerja bukan merupakan variabel intervening bagi budaya organisasi terhadap kinerja. Hasil penelitian ini tidak sesuai dengan pendapat Kotter dan Heskett (1992:9) yang menyatakan bahwa budaya organisasi yang kuat akan berpengaruh positif terhadap kinerja bisnis karena dapat memberikan motivasi luar biasa pada karyawan.

\section{KESIMPULAN}

Berdasarkan hasil penelitian dan pembahasan pada bab sebelumnya,maka dapat ditarik kesimpulan sebagai berikut :

1. Budaya organisasi berpengaruh positif dan signifikan terhadap kinerja pegawai. Hal ini menunjukkan bahwa semakin tinggi budaya organisasi yang terjadi, maka akan terjadi peningkatan kinerja pegawai pada PT. Rahmat Jaya Perkasa.

2. Budaya organisasi berpengaruh positif dan signifikan terhadap motivasi kerja. Hal ini menunjukkan bahwa semakin tinggi budaya organisasi yang terjadi, maka akan terjadi peningkatan motivasi kerja pegawai pada PT. Rahmat Jaya Perkasa.

3. Motivasi kerja berpengaruh signifikan terhadap kinerja pegawai. Hal ini menunjukkan bahwa semakin tinggi motivasi kerja yang terjadi, maka akan terjadi peningkatan kinerja pegawai pada PT. Rahmat Jaya Perkasa.

4. Berdasarkan perhitungan dari penelitian ini, motivasi kerja bukan merupakan variabel intervening atau tidak memediasi pengaruh antara budaya organisasi terhadap kinerja pegawai. Besarnya koefisien pengaruh langsung antara budaya organisasi dengan kinerja pegawai $(0,475)$ lebih besar daripada pengaruh tidak langsung antara budaya organisasi dengan kinerja pegawai melalui motivasi kerja $(0,267)$. Hal ini didasari oleh faktor dari motivasi dari Abraham Maslow, merupakan penghargaan diri dan pengakuan serta penghargaan tidak didukung dengan baik melalui jenjang karir yang meningkat apabila mengalami pencapaian tertentu.

\section{SARAN}

1. Bagi perusahaan diharapkan meningkatan kinerja pegawai terutama pada indikator kualitas dalam ketelitian dalam mengerjakan tugas, yaitu dengan mengadakan pelatihan pendalaman keterampilan profesi dari pegawai 
senior ataupun dari profesional yang menguasai bidang tersebut.

2. Bagi perusahaan diharapkan dapat menambah jenjang karir untuk menambah motivasi yang berada dalam perusahaan sehingga motivasi karyawan yang berada dalam perusahaan meningkat.

3. Penelitian ini memiliki berberapa keterbatasan yaitu sampel penelitian ini hanya terbatas pada karyawan tetap, sehingga perlu dilakukan generalisasi yang lebih baik dengan menambahkan karyawan tidak tetap.

\section{REFERENSI}

Ardhyan Krisdiyanto. 2010. Analisis Faktor-Faktor Yang Mempengaruhi Motivasi dan Pengaruhnya Terhadap Kinerja Karyawan.Jurnal Ilmu Ekonomi ASET, (Online), Vol.12, No,1, pp. 1-16. (http://jurnal.widyamanggala.ac.id diakses 15 April 2016)

Bungin, Burhan.2006. Metode Penelitian Kualitatif. Edisi Pertama.Jakarta: Kencana

Darmadi, Hamid. 2011. Metode Penelitian Pendidikan. Cetakan Pertama. Bandung: Alfabeta.

Dessler, Gary. 2011. Human Resource Management 8th Edition. New Jersey: Prentice-Hall, Inc.

Dewi Lina.2012. Analisis Pengaruh Kepemimpinan dan Budaya Organisasi Terhadap Kinerja Pegawai Dengan Sistem Reward Sebagai Variabel Moderating.Jurnal Riset Akuntasi dan Bisnis, (Online), Vol.14, No.1, pp.7797. (http://jurnal.umsu.ac.id diakses 15 April 2016)

Dina Rahmayanti dan Idham Afandi. 2014. Analisis Pengaruh Kepemimpinan, Motivasi, Lingkungan Kerja dan Kedisiplinan Terhadap Kinerja Karyawan.Jurnal Optimasi Sistem Industri, (Online), Vol.13, No.1, pp.556(http://industri,ft.unand.ac.id diakses 15 April 2016)

Indri Djastuti dan Meyta Indraswari.2014. Pengaruh Budaya Organisasi Dan Motivasi Terhadap Kepuasan Kerja Dalam Mempengaruhi Kinerja Karyawan Kantor Unit PT Telkom Regional IV Semarang.(Online), (http://undip.ac.id diakses 15 April 2016)

Erlina, Sri Mulyani, 2007. Metodologi Penelitian Bisnis : Untuk Akuntansi dan Manajemen, Cetakan Pertama. Medan: USU Press

Gareta , Sella. 2016. Infrastruktur Digenjot, Industri Keramik Berpeluang Besar,

(Online),(http://m.antaranews.com/berita/550554/infr astruktur-digenjot-industri-keramik-berpeluangbesar.html, diakses 21 April 2016).

Ghozali, Imam. 2014. Structural Equation Modelling Metode Alternatif Dengan Partial Least Square. Edisi Empat. Semarang: Universitas Diponegoro

Handoko., 2008. Manajemen Personalia dan Sumber Daya Manusia.Edisi 2. Yogyakarta: BBPE.

Hashim Zameer, Shehzad Ali, Waqar Nizar, dan Muhammad Amir. 2014. The Impact of the Motivation on the Employee's Performance in Beverage Industry of Pakistan.International Journal, (Online), Vol. 4, No.1, January 2014, pp. 293-298.

Kesuma, Ali. 2007. Pengaruh Lingkungan Kerja, Motivasi dan Budaya Organisasi terhadap Kepuasan serta dampaknya terhadap Kinerja Pegawai. Jurnal Bisnis dan
Manajemen, (Online), Vol.1, No.4, pp. 310-322. (http://pdii.lipi.go.id, diakses 15 April 2016).

Luthans, Fred. 2006. Perilaku Organisasi, (Alih Bahasa V.A Yuwono, dkk),Edisi Bahasa Indonesia. Yogyakarta: ANDI.

Mangkunegara, Anwar. 2015. Manajemen Sumber Daya Manusia.Cetakan Kedua belas. Bandung: PT. Remaja Rosdakarya.

Moerdani, Soma. 2010.Pengaruh Budaya Organisasi Terhadap Kinerja Karyawan Dinas PU Cipta Karya Dan Tata Ruang Provinsi Jawa Timur Dengan Motivasi Sebagai Variabel Intervening.Skripsi tidak diterbitkan. Surabaya: PPs Universitas Airlangga Surabaya.

Riani, Asri Laksmi.2011.Budaya Organisasi, Cetakan Pertama, Yogyakarta: Graha Ilmu.

Robbins, S.P. 2003. Organizational Behaviour. Prentice Hall, New Jersey

Robbins, Stephen. P. 2006.Perilaku Organisasi (alih bahasa Drs. Benjamin Molan),Edisi Bahasa Indonesia. Edisi Kesepuluh. Jakarta: PT.Indeks.

Robbins, Stephen P. 2008. Perilaku Organisasi, Buku 2. Jakarta: Salemba Empat

Sinha, Smrita., Singh, Ajay Kr., dan Gupta, Nisha., dan Dutt, Rajul. 2010. Impact of Work Culture on Motivation and Performance Level of Employees in Private Sector Companies. Acta Oeconomica Pragensia, (Online), Vol.18, No.6, pp. 49-67. (http://pragnesia.com, diakses 15 April 2016).

Sopiah. 2008.Perilaku Organisasional.Yogyakarta : CV. Andi Offset.

Staf Kepresidenan RI. 2015. Dampak

Pembangunan Infrastruktur Mulai Terasa, (Online), (http://presidenri.go.id/infrastruktur/dampak-

pembangunan-infrastruktur-mulai-terasa.html, diakses 15 Mei 2016).

Sugiyono. 2009. Metode Penelitian Kuantitatif dan Kualitatif. Bandung: CV.Alfabeta.

Sugiyono. 2014. Statistik untuk Penelitian. Cetakan ke 25. Bandung: Alfabeta.

Sugiyono. 2010. Statistik untuk Penelitian. Bandung: Alfabeta.

Sutrisno,Edy.2011.Budaya Organisasi, Cetakan

Kedua. Jakarta: Media Group.

Susanto, Heri dan Aisiyah, Nuraini.2010. Analisis Pengaruh Kepemimpinan dan Budaya Kerja dengan Motivasi sebagai Variabel Intervening terhadap Kinerja Karyawan di Kantor Pertahanan Kabupaten Kebumen. Jurnal Manajemen Sumber Daya Manusia, (Online), Vol.2, No.1, pp. 15-38. (http://pdii.lipi.go.id, diakses 17 April 2016).

Teguh, Wahyono. 2012. Analisis Statistik Mudah SPSS 20. Edisi 1. Jakarta: PT. Elex Media Komputindo.

Pabundu Tika. 2014. Budaya Organisasi dan Peningkatan Kinerja Perusahaan,Cetakan Kelima.Jakarta: PT. Bumi Aksara

Uno, Hamzah B., 2008, Orientasi Baru dalam Psikologi Pembelajaran, cetakan kedua,Jakarta: PT Bumi Aksara.

Wildan, Muh Alkirom. 2010. Pengaruh Karakteristik Individu dan Budaya Organisasi terhadap Motivasi Kerja dan Kreativitas Kerja serta Kinerja Karyawan Internal 
BISMA - Bisnis dan Manajemen -Volume 9 No. 1 Oktober 2016

Auditor pada Bank BUMN di Indonesia.Tesis tidak diterbitkan. Surabaya: PPs Universitas Airlangga Surabaya.

Wibowo. 2012.Manajemen Perubahan, Cetakan Keempat. Jakarta: Rajawali Pers
Wibowo. 2010. Budaya Organisasi: Sebuah Kebutuhan Untuk Meningkatkan Kinerja Jangka Panjang. Cetakan Pertama. Jakarta: PT Raja Grafindo Persada 